
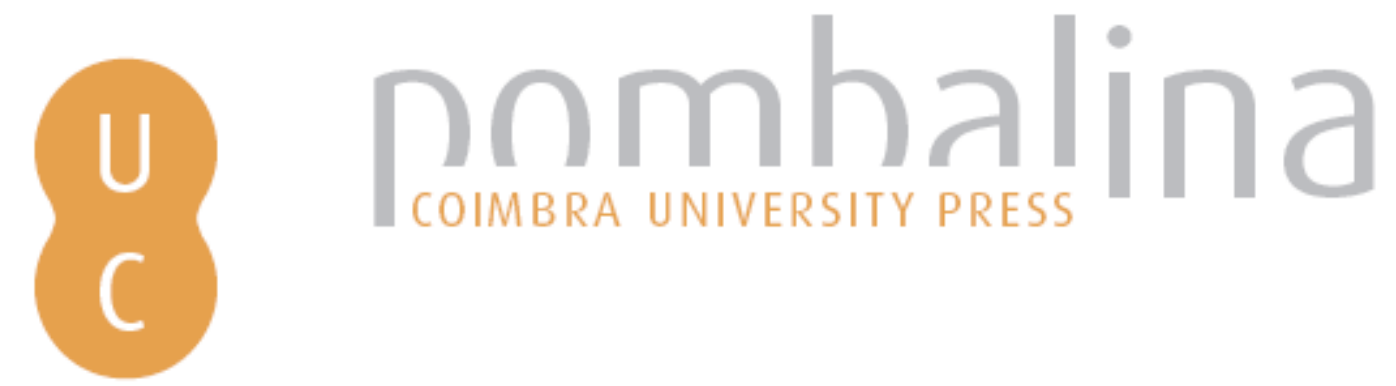

\title{
Soil resilience under different scenarios of fire recurrence and severity in Pinus forest ecosystems affected by large wildfires
}

\begin{tabular}{ll} 
Autor(es): & Marcos, Elena; Fernández-García, Victor; Fernández-Guisuraga, José \\
Publicado por: & Imprensuel; Fernández-Manso, Alfonso; Quintano, Carmen; Calvo, Leonor \\
$\begin{array}{ll}\text { URL } \\
\text { persistente: }\end{array}$ & URI:http://hdl.handle.net/10316.2/44548 \\
DOI: & DOI:https://doi.org/10.14195/978-989-26-16-506_31 \\
Accessed : & 26-Apr-2023 10:27:33 \\
\hline
\end{tabular}

A navegação consulta e descarregamento dos títulos inseridos nas Bibliotecas Digitais UC Digitalis, UC Pombalina e UC Impactum, pressupõem a aceitação plena e sem reservas dos Termos e Condições de Uso destas Bibliotecas Digitais, disponíveis em https://digitalis.uc.pt/pt-pt/termos.

Conforme exposto nos referidos Termos e Condições de Uso, o descarregamento de títulos de acesso restrito requer uma licença válida de autorização devendo o utilizador aceder ao(s) documento(s) a partir de um endereço de IP da instituição detentora da supramencionada licença.

Ao utilizador é apenas permitido o descarregamento para uso pessoal, pelo que o emprego do(s) título(s) descarregado(s) para outro fim, designadamente comercial, carece de autorização do respetivo autor ou editor da obra.

Na medida em que todas as obras da UC Digitalis se encontram protegidas pelo Código do Direito de Autor e Direitos Conexos e demais legislação aplicável, toda a cópia, parcial ou total, deste documento, nos casos em que é legalmente admitida, deverá conter ou fazer-se acompanhar por este aviso.

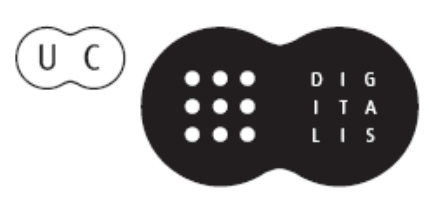




\section{ADVANCES IN}

\section{FOREST FIRE RESEARCH}

\section{8}

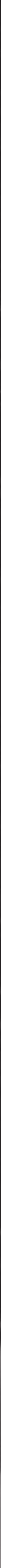




\title{
Soil resilience under different scenarios of fire recurrence and severity in Pinus forest ecosystems affected by large wildfires
}

\author{
Elena Marcos ${ }^{1 *}$; Victor Fernández-García ${ }^{1}$; José Manuel Fernández-Guisuraga ${ }^{1}$; Alfonso \\ Fernández-Manso $^{2}$; Carmen Quintano ${ }^{3}$; Leonor Calvo ${ }^{1}$ \\ ${ }^{1}$ Area of Ecology. Faculty of Biological and Environmental Sciences. University of León, 24071 \\ León.\{elena.marcos@unileon.es*\} \\ ${ }^{2}$ Agrarian Engineering Department, University of León, Av. Astorga s $n$, Ponferrada, Spain \\ ${ }^{3}$ Electronic Technology Department, Sustainable Forest Management Research Institute, \\ University of Valladolid, Spanish National Institute for Agriculture and Food Research and \\ Technology (INIA), C/Francisco Mendizábal s/n, 47014 Valladolid, Spain.
}

\begin{abstract}
Fire is as a global phenomenon that represents one of the main disturbances in the Mediterranean Pinus forest ecosystem. It is also considered to be a soil forming factor and temporary modifier of soil properties. The degree of this impact depends on different factors such as pre-fire conditions, the type of soils affected, topographic and metereological characteristics and fire-regime attributes (e.g. fire size, recurrence, burn severity). In the last few decades, the fire regime is changing in some regions of the world including the Iberian Peninsula. This is the result of land abandonment, fire suppression policies and climate change. These factors generate a more favourable environment for the occurrence of large forest fires that may play a key role in affecting the natural rates and patterns of soils structure and functioning. As a consequence, both resiliency and sustainability of Mediterranean Pinus forest could be engaged. This survey is aimed at getting to know the effects of combined fire-regime attributes (recurrence and severity) on soil biochemical properties from a medium-term perspective (four years).

The study was conducted in the Sierra del Teleno mountain range (León province; NW Iberian Peninsula). The climate is Mediterranean with 2-3 months' dryness in summer. Soils are acidic (pH around 4.8) and mainly classified as Cambisol and Leptosol. A large wildfire occurred on August $19^{\text {th }} 2012$ affected an area of $119 \mathrm{~km}^{2}\left(103 \mathrm{~km}^{2}\right.$ being occupied by Pinus pinaster Ait. forests). In this wildfire, a fire recurrence-severity map was elaborated by remote sensing methods, and validated using ground truth and with the information provided by the Regional Administration. We characterized fire recurrence throughout a 16-year period (1998-2014). Fire severity was measured by the dNBR (difference of the Normalized Burn Ratio) spectral index, and classified according to the ground reference values of the CBI (Composite Burn Index). We differentiated four scenarios of recurrence (low and high) and severity (low and high), and established a minimum of five $30 \mathrm{~m} * 30 \mathrm{~m}$ field plots in each of the four recurrence-severity scenarios. In each field plot, we collected soil samples from a depth of $0-3 \mathrm{~cm}$ four years after the fire, and analysed the enzymatic activities $\beta$-glucosidase, urease, and acid-phosphatase and microbial biomass carbon.

Four years after the fire, it can be observed that fire-regime attributes have a great influence on the resilience of soil properties. In the scenario of low recurrence-high severity, which means the highest intensity fire, decreased phosphatase and urease activities and soil microbial biomass carbon. This scenario showed a slight resilience to $\beta$-glucosidase activity but marked depletion in the other soil properties. High recurrence scenarios favour the recovery of soil biochemical and microbial properties. Soil enzymatic activities and microbial biomass could be a proxy to identify the general state of soil health after large fires.
\end{abstract}

Keywords: enzymatic activities, medium-term, post-fire, recovery, soil microbial biomass, wildfires

\section{Introduction}

Fire is an important process which causes severe disturbances in many ecosystems, mainly in Mediterranean forest ecosystem. In this region, forests most affected by fire are pine ecosystems 
(Moreira et al., 2008) with Pinus pinaster Ait. and Pinus halepensis Mill. as the dominant species. Fire impact on the ecosystem depends on different factors such as forest structure (Jain \& Graham 2007; Shive et al., 2013), topographic and meteorological characteristics (Fang et al., 2018; Moreno \& Chuvieco, 2016) and fire-regime attributes (Fernández et al., 2018).

In the last few decades, fire regime is changing in some regions of the world such as the Iberian Peninsula. This is the result of land abandonment, fire suppression policies and climate change (Moreno et al., 2014). These factors generate a more favourable environment for the increase in number and size of fires and thus in fire frequency (Guénon et al., 2013) and severity. As a consequence, natural rates and patterns of soil structure and functioning could be altered. Fire severity, defined as the loss of or change in biomass of the ecosystem caused by fire (Keeley, 2009), is used as an indicator of the fire's indirect impacts on the hydrological response of burned areas (Vieira et al., 2015). This is associated with negative effects mainly in soil physical properties such as water repellency and aggregate stability, and it is attributed to the changes in soil organic matter (Varela et al., 2015; Merino et al., 2018). Likewise, fire severity is a dominant factor in explaining changes in soil microbial communities and soil enzyme activity (Knelman et al., 2015), constraining the post-fire functioning of the ecosystem. On the other hand, fire recurrence continuously impoverishes soil especially in terms of organic matter and nutrients (Knicker, 2007) which would negatively affect to the recovery of microbial activities and increased the loss of ecosystem resilience in the long-term (Guénon et al., 2013).

On the other side, soil microbial biomass and enzyme activities are considered good indicators of soil quality and the impact of fire on soil (López-Poma \& Bautista, 2014; Hinojosa et al., 2016). These properties are more sensitive to soil management practices or disturbances than chemical and physical ones (Dilly et al., 2018). The highest soil microbial content is found in natural ecosystems (woods and pastures) while this content decreases in managed ecosystems (crops and plantations) (Dilly et al., 2018) or in severely burned soils (Vega et al., 2013). The activity of soil enzyme is generally reduced immediately after fire (Vega et al., 2013; López-Poma \& Bautista, 2014). The persistence of this impact can be ephemeral or persist several years according to the capacity of establishment of plant communities (Knelman et al., 2015) and the resilience of soil enzyme activity (López-Poma \& Bautista, 2014).

Although different research has evaluated the effects of fire recurrence (Guénon et al., 2013) or fire severity (Vega et al., 2013) in both biochemical and microbiological soil properties, there are not studies analyzing the effects of the combination of fire regime attributes (recurrence and severity) in them. For this reason, the present survey is aimed at determining to know the role of combined fireregime attributes (recurrence and severity) in soil resilience of biochemical and microbiological properties from a medium-term perspective (four years).

\section{Material and methods}

\subsection{Study area}

The study was conducted in the Sierra del Teleno mountain range (León province; NW Spain) The climate is Mediterranean temperate with an annual precipitation of 650-900 mm (Quintano et al., 2015) and an average temperature of around $11^{\circ} \mathrm{C}$. The area is characterised by a heterogeneous orography, with an elevation above sea level ranging from 850 to $2100 \mathrm{~m}$. The lithologies are siliceous, and dominated by stones, silts, clays and conglomerates in the flat areas, and slate, sandstone, and quartzite in the mountainous ones (IGME, 1982). The soils are classified as Cambisol and Leptosol (Forteza et al., 1987) with a $\mathrm{pH}$ around 5, low soil organic carbon content $(\sim 2 \%)$, total nitrogen $(\sim 0.1 \%)$ and available phosphorous $\left(<5 \mathrm{mg} \mathrm{kg}^{-1}\right)$. The vegetation present before fire was covered mainly by Pinus 
pinaster Ait. with an understorey layer dominated by Erica australis L., Pterospartum tridentatum (L.) Willk., and Halimium lasianthum spp. alyssoides (Lam.) Greuter (Santalla et al., 2002)

Fires caused by dry spring-summer storms occur frequently in this forest ecosystem, but usually affect small areas. Nevertheless, a large fire occurred on 19th August 2012. This fire burned $119 \mathrm{~km}^{2}$ being $103 \mathrm{~km}^{2}$ being occupied by $P$. pinaster forests, with a tree age of 35-95 years old. The weather conditions during the first day were $32^{\circ} \mathrm{C}$ and $27 \%$ relative humidity. There was a very significant accumulated drought, with Haines index values of 6 (Quintano et al., 2015).

\subsection{Field data collection and soil analysis}

In this wildfire, a fire recurrence-severity map was elaborated by remote sensing methods, and validated using ground truth and with the information provided by the Regional Administration (Fernández-Manso et al., 2015) (Figure 1). To determine fire recurrence we considered the period 1998-2014 and classified as low (1 fire) and high (2 fires) recurrence. In order to characterise fire severity, we calculated the dNBR spectral index (Key, 2006) from the Landsat 7 ETM+ scenes of September 20th, 2011 (pre-fire situation) and September 6th, 2012 (post-fire). Four years after wildfire, a total of 44 field plots of $30 \mathrm{~m}$ x $30 \mathrm{~m}$ were established in four recurrence scenarios (low and high) and burn severity (low and high). The plots were randomly distributed in these scenarios with a minimum of 5 plots per recurrence-severity category: 10 plots for low recurrence-low severity; 10 plots for low recurrence-high severity; 10 plots for high recurrence-low severity and 14 plots for high recurrence-high severity.

To evaluate soil resilience, we collected two soil composite samples from each 30 x $30 \mathrm{~m}$ plot. Each soil sample was made up of four subsamples. The soil subsamples were collected along two $15 \mathrm{~m}$ perpendicular transects (N-W and S-W), after removing litter and plant debris from the surface, using an auger $(5 \mathrm{~cm}$ diameter $\times 3 \mathrm{~cm}$ depth). This approach would allow the variability of the $30 \times 30$ plot to be captured. The soil samples were mixed, air-dried, sieved $(<2 \mathrm{~mm})$ and stored at ambient temeperature for further analysis.

In these samples, we analysed three soil extracellular enzymatic activities corresponding to the biogeochemical cycles of $\mathrm{C}, \mathrm{N}$ and $\mathrm{P}$. Soil acid phosphatase and $\beta$-glucosidase activities were determined colorimetrically as the amount of $\mathrm{p}$-nitrophenol ( $\mathrm{p}-\mathrm{NP}$ ) produced after incubation of 0.5 and $1 \mathrm{~g}$ of soil $\left(37^{\circ} \mathrm{C}, 1 \mathrm{~h}\right)$ with p-nitrophenyl-phosphate and p-nitrophenyl- $\beta$-D-glucopyranoside substrates, respectively (Tabatabai and Bremner, 1969; Tabatabai, 1982). The p-NP formed was determined in a spectrophotometer at $400 \mathrm{~nm}$ (UV-1700 PharmaSpec, Shimadzu, Kyoto, Japan). Urease activity was determined following Kandeler \& Gerber (1988) as the amount of N-NH4+ released from $1 \mathrm{~g}$ of soil after incubation $\left(37^{\circ} \mathrm{C}, 2 \mathrm{~h}\right)$ with urea substrate. The $\mathrm{N}-\mathrm{NH} 4+$ released was measured colorimetrically at $690 \mathrm{~nm}$. Two sample blanks for each soil sample were used.

Soil microbial biomass $\mathrm{C}$ content was determined by the fumigation-extraction method (Vance et al., 1987). This procedure is based on a Walkley-Black dichromate digestion to calculate the difference $\left(\mathrm{E}_{\mathrm{C}}\right)$ in organic $\mathrm{C}$ between filtered extracts of chloroform fumigated $(\mathrm{CHCl} 3,24 \mathrm{~h})$ and non-fumigated soil samples. Then, we used an extraction efficiency coefficient $\left(\mathrm{k}_{\mathrm{EC}}\right)$ of 0.38 (Vance et al., 1987; Joergensen, 1996) to calculate the microbial biomass $\mathrm{C}$ following the formula: microbial biomass $\mathrm{C}=$ $\mathrm{E}_{\mathrm{C}} / \mathrm{k}_{\mathrm{EC}}$. 


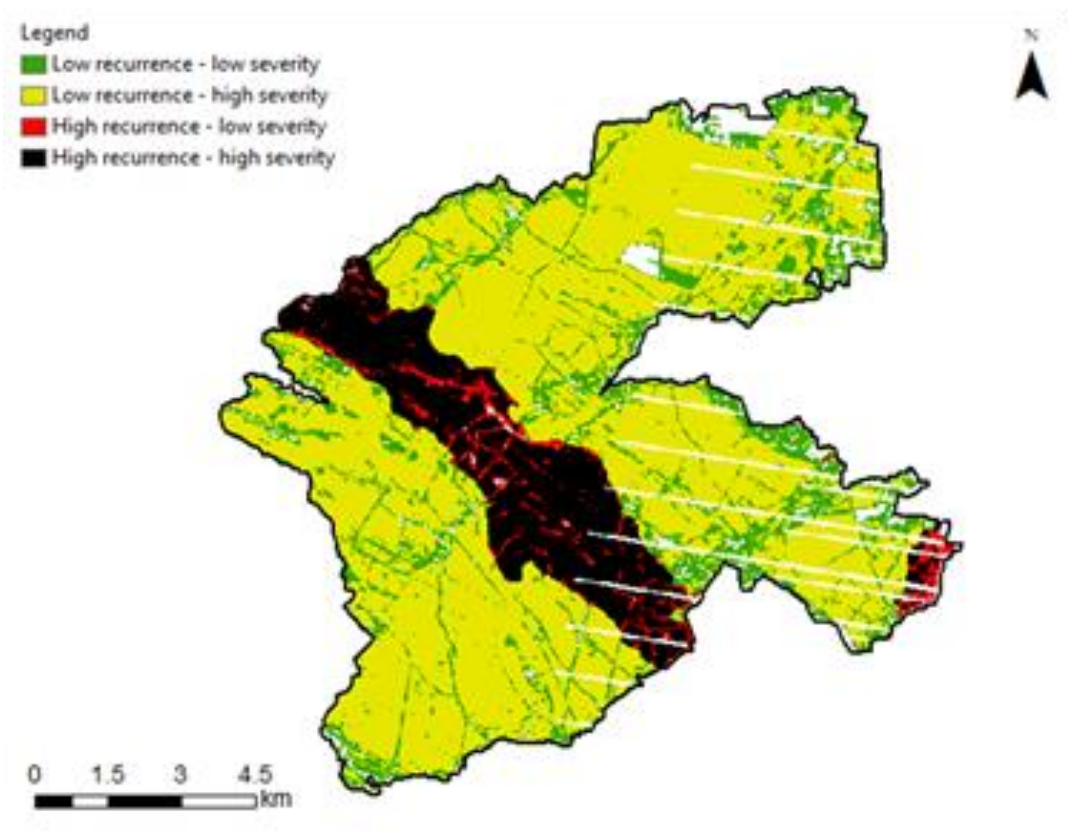

Figure 1 - Map of recurrence-burn severity levels in the study area

\subsection{Resilience index}

The soil enzymatic and microbial biomass resilience to different recurrence and severity scenarios was calculated using the resilience index developed by Banning \& Murphy (2008):

$$
R x=-100\left[\frac{C x-P x}{P x}\right]
$$

Where $\mathrm{Rx}$ is the reslience index; $\mathrm{Cx}$ is the value in the response variable in the low recurrence-low severity scenario, which was considered as a control value; $\mathrm{Px}$ is the value for the response variable in the other scenarios four years after fire. A Rx index value of zero indicates complete recovery at a given time $\mathrm{x}$. Positive values indicate resilience of the response variable, while an Rx value of -100 indicates a further degradation of soil response variable.

\subsection{Data analysis}

In order to analyse the effects of recurrence-severity situations on soil biochemical and microbiological properties, we performed an ANOVA of the Generalised Linear Models (GLMs). GLMs were fitted using Gamma error distribution with the "log" link function. The goodness of fit of the models was assessed by visual analysis of homoscedasticity and normality of residuals. Differences in treatment levels were identified through a pairwise multiple comparison of means (Tukey HSD).

All data analyses were carried out with R software, version 3.4.0, using the "multcomp" package (Hothorn et al.,2008).

\section{Results}

Medium-term enzyme activities of $\beta$-glucosidase and acid phosphatase and urease showed a different pattern among the scenarios of recurrence and severity. $\beta$-glucosidase activity increased significantly (Table 1; Figure 2;) from the best scenario (low recurence-low severity) to the worst (high recurrence-high severity). 
Table 1 - Results of the generalized linear models (GLMs) ['Anova()' outputs] showing the effects of the factor recurrence-severity (Low-Low, Low-High, High-Low and High-High) on each soil property ( $\beta$-glucosidase, urease, phosphatase and microbial biomass $C$ ). Df are degrees of freedom. Significant $P$-values are in bold face.

\begin{tabular}{|c|c|c|c|c|c|c|}
\hline Response variable & Model term & Df & Deviance & $\begin{array}{l}\text { Residual } \\
\text { deviance }\end{array}$ & $\mathrm{F}$ & $P$ \\
\hline \multirow{2}{*}{$\beta$-glucosidase } & Null & & & 13.440 & & \\
\hline & Recurrence-Severity & 3 & 1.486 & 11.954 & 3.010 & 0.035 \\
\hline \multirow{2}{*}{ Urease } & Null & & & 32.648 & & \\
\hline & Recurrence-Severity & 3 & 5.270 & 27.378 & 5.864 & 0.001 \\
\hline \multirow{2}{*}{ Phosphatase } & Null & & & 37.344 & & \\
\hline & Recurrence-Severity & 3 & 6.315 & 31.029 & 4.655 & 0.004 \\
\hline \multirow{2}{*}{ Soil microbial C } & Null & & & 26.189 & & \\
\hline & Recurrence-Severity & 3 & 4.321 & 21.869 & 5.457 & 0.002 \\
\hline
\end{tabular}

A different pattern was observed in urease activity with a significant decrease (Table 1; Figure 2) in the low recurrence-high severity scenario. In the case of acid phosphatase, significant differences were detected among high recurrence scenarios, and the low recurrence-high severity situation (Table 1 ; Figure 2) which presented the highest activity values.

Soil microbial carbon showed the lowest significant value in the low recurrence-high severity scenario (Figure 2; Table 1). We did not find significant differences amongst the remaining situations.
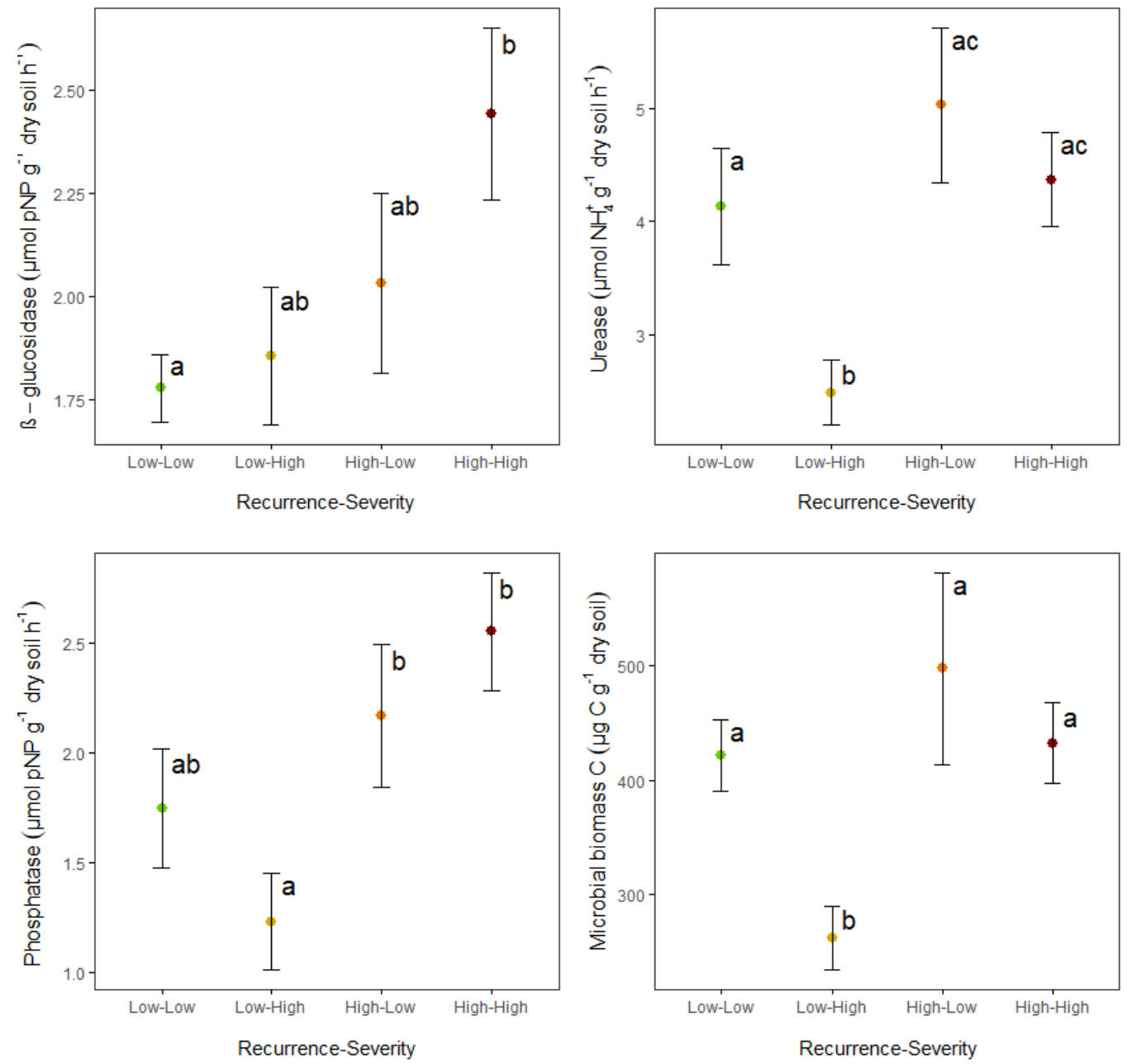

Figure 2 - Mean values \pm standard error of soil properties ( $\beta$-glucosidase, urease, phosphatase and microbial biomass

C) in relation to the fire recurrence-severity (low recurrence-low severity, low recurrence-high severity, high recurrence-low severity and high recurrence-high severity). Different letters above the error bars $(a, b, c)$ denote statistically significant differences between mean values $(p<0.05)$. 
Soil enzymes showed different resilience capacity in relation different scenarios of recurrenceseverity. $\beta$-glucosidase activity recovered well in all situations, reaching always higher values than low recurrence-low severity (Figure 2). Ureasa and acid phosphatase activities presented negative resilience values in low recurrence-high severity scenario (39\% and $27 \%$ respectively) but good resilience in relation both high recurrence situations (Table 2). The same pattern was observed in soil microbial carbon, with an important degradation in low recurrence-high severity scenario (Table 2) but a good recovery in the other ones, mainly if the severity is low.

Table 2- Percentage of resilience (Rx) of soil enzymatic activities and microbial biomass in different scenarios of fire recurrence-severity scenarios (Low-High, High-Low and High-High)

\begin{tabular}{|c|c|c|c|c|c|}
\hline $\begin{array}{l}\text { Scenarios fire } \\
\text { severity scenarios }\end{array}$ & recurrence- & $\beta$-glucosidase & Urease & Phosphatase & $\begin{array}{l}\text { Soil microbial } \\
\text { C }\end{array}$ \\
\hline Low-High & & $3.0(13)$ & $-39.4(10)$ & $-27.7(18)$ & $-37.7(9)$ \\
\hline High-Low & & $12.8(12)$ & $22.7(23)$ & $27.3(27)$ & $18.0(28)$ \\
\hline High-High & & $35.6(13)$ & $6.6(12)$ & $50.0(18)$ & $2.6(10)$ \\
\hline
\end{tabular}

Values are means for each recurrence-severity scenario ( $\mathrm{n}=10$ for Low-High and High-Low and $\mathrm{n}=20$ for High-High) with standard errors in parenthesis.

\section{Discussion}

This study examined the resilience of soil biochemical and microbiological properties to a combination of fire regime attributes: recurrence and severity. Our results demonstrated that the low recurrence-high severity scenario was the worst situation for the recovery of biochemical and microbiological properties throghout time. In this scenario (at least 14 years without fire), both the fuel load and the intensity and severity of fire. This could influence in the post-fire regeneration traits of plant species which modulate soil enzymatic activity recovery (López-Poma \& Bautista, 2014). In this study area, we found that high severities negatively affected the cover of resprouter species but positively affected seeder species (Fernández-García et al., 2017). However, in the high recurrence scenarios the highest cover was due to resprouter shrubs, which rapidly increased their cover after fire. We found greater enzyme activity in those situations where resprouter species are dominant (high recurrence), because after a fire, the root system of the resprouter species is scarcely affected by fire, the microbiological rhyzosphere hotspots are more durable, and enzyme inputs to soils from root exudates are not interrupted (Mayor et al., 2016). Furthermore, the regeneration of resprouter species is very rapid and presents more nutrient demand and rhizosphere activity (López-Poma \& Bautista, 2014).

On the other hand, enzyme activity showed a different response with regard to resilience. While $\beta$ glucosidase activity showed a positive recovery trend in all scenarios, acid phosphatase and urease showed a positive recovery under high recurrence scenarios but a degradation in low recurrence-high severity scenarios. Some authors have pointed out that the highest increase in $\beta$-glucosidase activity is related to greater plant density (Guénon et al., 2013), since there is an increase in enzyme substrate due to litter deposition and this produces an increase in the number of microorganisms (Mayor et al., 2016). The decrease in acid phosphatase and urease activity in the low recurrence-high severity scenario can be the result of of great availability of inorganic $\mathrm{N}$ and $\mathrm{P}$, which often persist at mediumterm after fire (Dzwonko et al., 2015), as in our study area (data unpublished). If the concentrations of nutrients is high, micro-organisms do not need to produce these extracellular enzymes (Pourreza et al., 2014), since they are substrate-dependent.

Although microbial biomass is markedly reduced by fire (Banning \& Murphy, 2008), four years after it showed a good resilience except in the low recurrence-high severity scenario. This low resilience would be related with a decrease in the quality of soil organic matter, because of the 
emergence of new particulate $\mathrm{C}$ forms highly resistant to oxidation and biological degradation (González-Pérez et al., 2004) that act by limiting soil microbial recovery. However, frequent wildfires can enable the recovery of net nitrification and nitrate content, resulting in a recovery of $\mathrm{C}$-substrate utilisation capabilities of microbial communities (Guénon et al., 2013) .Microbial biomass recovery was assessed by Prieto-Fernández et al. (1998) in a soil under Pinus spp. four years after fire, and was attributted to the addition of cellulose to the burnt soil favouring fungal mycelium development and the speed of plant recolonisation (Certini, 2005) and the litter layer.

The combination of fire regime attributes (recurrence and severity) had an important effect on soil resilience. High recurrence scenarios favour the recovery of soil biochemical and microbial properties, due to the rapid regeneration of resprouter species. Under these conditions urease activity and soil microbial biomass $\mathrm{C}$ do better if the severity is low, while an opposite pattern showed the other two enzyme activities. The low recurrence-high severity scenario negatively affects soil resilience, which results in a depletion of enzyme activities (except $\beta$-glucosidase) and soil microbial biomass $\mathrm{C}$.

\section{Acknowledgements}

This study was financially supported by the Spanish Ministry of Economy and Competitiveness, and the European Regional Development Fund (ERDF), in the framework of the GESFIRE (AGL2013-48189-C2-1-R) and FIRESEVES (AGL2017-86075-C2-1-R) projects; and by the Regional Government of Castile and León in the framework of the FIRECYL (LE033U14) and SEFIRECYL (LE001P17) projects.

\section{References}

Banning NC, Murphy DV (2008) Effect of heat-induced disturbance on microbial biomass and activity in forest soil and the relationship between disturbance effects and microbial community structure. Applied Soil Ecology 40, 109-119.

Certini G (2005) Effects of fire on properties of forest soils: a review. Oecologia 143, 1-10.

Dilly O, Pompili L, Benedetti A (2018) Soil micro-biological indicators separated land use practices in contrast to abiotic soil properties at the $50 \mathrm{~km}$ scale under summer warm Mediterranean climate in nirthern Italy. Ecological Indicators 84, 298-303.

Dzwonko Z, Loster S, Gawronski S (2015) Impact of fire severity on soil properties and the development of tree and shrub species in a Scots pine moist forest site in southern Poland. Forest Ecology and Management 342, 56-63.

Fang L, Yang J, White M, Liu Z (2015) Predicting potential fire severity using vegetation, topography and surface moisture availability in a Eurasian Boreal Forest Landscape. Forests 9, 130.

Fernández-García V, Quintano C, Taboada A, Marcos E, Calvo L, Fernández-Manso A (2018) Remote sensing applied to the study of fire regime attributes and their influence on post-fire greenness recovery in pine ecosystems. Remote Sensing 10, 733.

Fernández-García V, Baeza J, Santana VM, Tárrega R, Valbuena L, Taboada A, Luis-Calabuig E, Fernández-Guisuraga JM, Suárez-Seoane S, Marcos E, Calvo L (2017) ¿Son diferentes los rasgos biológicos de las plantas en relación con la severidad de incendios en pinares propensos al fuego? Actas del $7^{\circ}$ Congreso Forestal Español, Plasencia. .pp. 1-10.

Fernández-Manso F, Fernández-García V, Quintano C, Marcos E, Calvo L (2015) Cartografía de recurrencia-severidad en grandes incendios forestales utilizando técnicas de teledetección. Actas del XVI Congreso de la AET. Sevilla, Spain. 
Forteza J, Lorenzo L, Najac N, Cuadrado S, Ingelmo F, Hernández J, García P, Prat L, Mulez C, Macarro C, Rivas D (1987) Mapa de suelos de Castilla y León, Scale 1:500000, Dirección General de Medio Ambiente y Urbanismo, Junta de Castilla y León, Valladolid.

González-Pérez JA, González-Vila FJ, Almendros G, Knicker H (2004) The effect of fire on soil organic matter - a review. Environment International 30, 855-870.

Guénon R, Vennetier M, Dupuy N, Roussosi S, Pailleri A, Gros R (2013) Trends in recovery of Mediterranean soil chemical properties and microbial activities after infrequent and frequent wildfires. Land Degradation and Development 24, 115-128.

Hinojosa MB, Parra A, Laudicina VA, Moreno JM (2016) Post-fire soil functionality and microbial community structure in a Mediterranean shrubland subjected to experimental drought. Science of Total Environment 573, 1178-1189.

Hothorn T, Bretz F, Westfall P (2008). Simultaneous Inference in General Parametric Models. Biometrical Journal 50(3), 346--363.

IGME (1982) Instituto Geológico y Minero de España, Mapa Geológico de España, Scale 1:50000. Sheets 230 and 231. Ministerio de Industria y Energía, Madrid.

Jain TB, Graham RT (2007) The relarion between tree burn severity and forest structure in the Rocky Mountains. General Technical Report PSW-GTR-203. USDA Forest Service, Rocky Mountain Research Sattion, Ogden, UT.

Joergensen JG (1996) The fumigation-extraction method to estimate soil microbial biomass: calibration of the kEC value. Soil Biology and Biochemestry 28, 25-31.

Kandeler E, Gerber H (1988) Short term assay of soil urease activity using colorimetric determination of ammonium. Biology and Fertility of Soils 6, 68-72.

Keeley JE (2009) Fire intensity, fire severity and burn severity: A brief review and suggested usage. International Journal of Wildland Fire 18, 116-126.

Key CH (2006) Ecological and sampling constraints on defining landscape fire severity. Fire Ecology 2, 34-59.

Knelman JE, Graham EB, Trahan NA, Schmidt SK, Nemergut DR (2015) Fire severity shapes plant colonization effects on bacterial community structure, microbial biomass, and soil enzyme activity in secondary succession of a burned forest. Soil Biology \& Biochemistry 90, 161-168.

Knicker H (2007) How does fire affect the nature and stability of soil organic nitrogen and carbon? A review. Biogeochemistry 85, 91-118.

López-Poma R, Bautista S (2014) Plant regeneration functional groups modulate the response to fire of soil enzyme activities in a Mediterranean shrubland. Soil Biology and Biochemistry 79, 5-13.

Mayor AG, Goirán SB, Vallejo VR, Bautista S (2016) Variation in soil enzyme activity as a function of vegetation amount, type, and spatial structure in fire-prone Mediterranean shrublands. Science of Total Environment 573, 1209-1216.

Merino A, Fonturbel MT, Fernández C, Chávez-Vergara B, García-Oliva F, Vega JA (2018) Inferring changes in soil organic matter in post-wildfire soil burn severity levels in a temperate climate. Science of Total Environmental 627, 622-632.

Moreira F, Arianoutsou M, Corona, P, De las Heras J (2012) 'Post-Fire Management and Restoration of Southern European Forests, Managing Forest Ecosystems'. pp. 319 (Springer Science + Business Media B.V.: Brussels).

Moreno MV, Chuvieco E (2016) Fire regime characteristics along environmental gradients in Spain. Forests 7, 262

Moreno MV, Conedera M, Chuvieco E, Boris G (2014) Fire regime changes and major driving forces in Spain from 1968 to 2010. Environmental Science Policy 37, 11-22. 
Pourreza M, Hosseini SM, Sinegani AAS, Matinizadeh M, Dick WA (2014) Soil microbial activity in response to fire severity in Zagros oak (Quercus brantii Lindl.) forests, Iran, after one year. Geoderma 213, 95-102.

Prieto-Fernández A, Acea MJ, Carballas T (1998) Soil microbial and extractable C and N after wildfire. Biology and Fertility of Soils 27, 132-142.

Quintano C, Fernández-Manso A, Calvo L, Marcos E, Valbuena L (2015) Land surface temperature as potential indicator of burn severity in forest Mediterranean ecosystems. International Journal of Applied Earth Observation 36, 1-12.

Santalla S, Salgado JM, Calvo L, Fernández M (2002) Changes in the Carabidae community after a large fire in a Pinus pinaster stand. In 'Fire and Biological Processes' (Eds L Trabaud, R Prodon, R) pp 215-231 (Backhuys Publishers. Leiden).

Shive KL, Sieg CH., Fulé PZ (2013) Pre-wildfire management treatments interact with fire severity to have lasting effects on post-wildfire vegetation response. Forest Ecology and Management 297, 75-83.

Tabatai MA (1982) Soil enzymes. In 'Methods of Soil Analyses, Part 2, Chemical and Microbiological Properties’. (Eds AL Page, EM Miller, DR Keeney) pp. 903-947 (American Society of Agronomy, Madison WI.)

Tabatai MA, Bremmer JM (1969) Use of p-nitrophenyl phosphate for assay of soil phosphatase activity. Soil Biology and Biochenistry 1, 301-307.

Vance ED, Brookes PC, Jenkinson DS, (1987) An extraction method for measuring soil microbial biomass C. Soil Biology and Biochemistry 19, 703-707.

Varela ME, Benito E, Keizer JJ (2015) Influence of wildfire severity on soil physical degradation in two pine forest stands of NW Spain. Catena 133, 342-348.

Vega JA, Fontúrbel T, Merino A, Fernández C, Ferreiro A, Jiménez E (2013) Testing the ability of visual indicators of soil burn severity to reflect changes in soil chemical and microbial properties in pine forests and shrubland. Plant and Soil 369, 73-91.

Vieira DCS, Fernández C, Vega JA, Keizer JJ (2015) Does soil burn severity affect the post-fire runoff and interrill erosion response? A review based on meta-analysis of field rainfall simulation data. Journal of Hydrology 523, 452-464. 